\title{
Spontaneous Viral Clearance in Sixteen HIV-Infected Patients with Chronic Hepatitis C
}

\author{
Jorge Soares $^{\mathrm{a}}$ João Vasco Santos ${ }^{\mathrm{b}-\mathrm{d}}$ António Sarmento $^{\mathrm{a}, \mathrm{e}}$ \\ Altamiro Costa-Pereira ${ }^{b, c}$ \\ ${ }^{a}$ Department of Infectious Diseases, Centro Hospitalar S. João/Faculty of Medicine, University of Porto, Porto, \\ Portugal; ${ }^{b}$ Department of Community Medicine, Information and Health Decision Sciences (MEDCIDS), Faculty of \\ Medicine, University of Porto, Porto, Portugal; ' CINTESIS - Centre for Health Technology and Services Research, \\ Porto, Portugal; d Public Health Unit, ACeS Grande Porto VIII - Espinho/Gaia, Porto, Portugal; e Nephrology and \\ Infectious Diseases R\&D Group INEB (I3S), University of Porto, Porto, Portugal
}

\section{Keywords}

Chronic hepatitis C · HIV/HCV coinfection · Drug-induced liver injury · Antiretroviral therapy · Spontaneous viral clearance

\footnotetext{
Abstract

Background/Aims: Spontaneous viral clearance of the chronic hepatitis $C$ virus ( $\mathrm{HCV}$ ) in human immunodeficiency virus (HIV)-infected patients is a rare event. We aimed to identify the clinical, therapeutic, demographic, and laboratory features associated with spontaneous HCV clearance in $16 \mathrm{HIV}$ infected patients with chronic hepatitis $\mathrm{C}$ (CHC, the largest case series, to our knowledge). Methods: This case series study reports the findings from $16 \mathrm{HIV} / \mathrm{HCV}$ coinfected patients with $\mathrm{CHC}$ who experienced spontaneous clearance of HCV infection. Patients were monitored between 2000 and 2013 in the Infectious Diseases Outpatient Clinic at the Centro Hospitalar S. João, Porto, Portugal. Results: Apart from antiretroviral therapy (ART), all patients were also consuming
}

other potential hepatotoxic drugs (e.g., alcohol, illicit drugs, methadone, and antituberculosis medication). In all but 1 of the $16 \mathrm{HIV}$-infected patients with $\mathrm{CHC}$, viral remission was associated with a temporary suspension of the ART. All patients showed a sustained HCV viral clearance. Conclusion: A possible drug-induced liver injury and/or suspension of ART may, in some cases, contribute to increasing the chances of spontaneous HCV clearance in HIV-infected patients with $\mathrm{CHC}$.

(c) 2018 S. Karger AG, Basel

\section{Background}

Hepatitis $\mathrm{C}$ virus ( $\mathrm{HCV}$ ) can lead to both acute and chronic hepatitis C (CHC) [1, 2]. Although 20-25\% of patients with $\mathrm{HCV}$ experience spontaneous clearance of the acute infection [3], the remainder develop CHC. CHC is a global public health problem affecting 141-175 million people worldwide [4]. It can also lead to cirrhosis, hepatocellular carcinoma, and liver-related death [2].

\section{KARGER}

(c) 2018 S. Karger AG, Basel

E-Mail karger@karger.com

www.karger.com/int
João Vasco Santos

Department of Community Medicine, Information and Health Decision Sciences (MEDCIDS), Faculty of Medicine, University of Porto

Alameda Prof. Hernâni Monteiro, PT-4200-319 Porto (Portugal)

E-Mail jvasco.santos@gmail.com 
Of the reported 40 million human immunodeficiency virus (HIV)-infected patients, $30-40 \%$ are also chronically infected with HCV [5]. HCV-related liver disease is the main cause of morbidity and mortality among these patients. Despite this, some of them are not treated for HCV infection [6, 7]. Moreover, although advanced treatments for $\mathrm{CHC}$ have been achieved (i.e., direct-acting antiviral agents [DAAs]), they are not available for the vast majority of patients worldwide due to economic reasons [8].

Spontaneous clearance of $\mathrm{HCV}$ in patients with $\mathrm{CHC}$ is a rare event, in contrast with acute infection. This event is even rarer in $\mathrm{HIV} / \mathrm{HCV}$ coinfected patients and is, still today, not a well-understood phenomenon [9]. There are not a lot of cases reported, but several authors have presented possible explanations such as immunologic recovery, antiretroviral therapy (ART) with protease inhibitors, transaminases flare-ups, HCV genotype or a polymorphism in interleukin (IL)28B alleles [10-28].

We have reported the largest case series (to the best of our knowledge) of HCV/HIV coinfected patients with $\mathrm{CHC}$ who experienced a spontaneous $\mathrm{HCV}$ clearance. In this study, we aimed to describe the clinical, therapeutic, demographic and laboratory features of these patients and which factors might have triggered the sustained viral clearance (SVC) of hepatitis C.

\section{Methods}

\section{Study Design}

This case series study was performed at the Infectious Diseases Outpatient Clinic at the Centro Hospitalar S. João, Porto, Portugal.

\section{Study Population}

A total of $842 \mathrm{HCV} / \mathrm{HIV}$ coinfected patients of European (Caucasian) origin were observed regularly in the period between 2000 and 2013. Data were collected by means of a complete review of the patients' medical history. Only patients with HCV/HIV coinfection and confirmed CHC infection were included in the study. Patient data included the following parameters: age, sex, the presence of AIDS (acquired immune deficiency syndrome, according to the 1993 revised criteria of the Centers for Disease Control and Prevention, Atlanta, GA, USA). The clinical data are presented in Table 1, Figure 1.

$\mathrm{CHC}$ duration was considered as the period between its diagnosis and the first negative test result for HCV. SVC of HCV was defined by 2 negative real-time polymerase chain reaction (RTPCR) test results separated by at least 6 months.

Viral Load Test

HCV RNA Quantification

Quantification of HCV RNA levels was done using RT-PCRbased assays using a fully automated system. HCV RNA was ex- tracted for the Cobas TaqMan HCV quantitative test v2.0 by means of a Cobas AmpliPrep automated extractor, according to the manufacturer's instructions. The Cobas TaqMan 96 analyzer was used for RT amplification and detection. The lower limit of HCV RNA detection was $15 \mathrm{IU} / \mathrm{mL}$.

HIV RNA Quantification

HIV viral load was determined with RT-PCR using the Cobas AmpliPrep/Cobas TaqMan HIV-1 test v2.0. Roche assay includes an automated sample preparation on the COBAS AmpliPrep instrument followed by real-time PCR and detection on the COBAS TaqMan instrument. The lower limit of detection was 20 copies/ $\mathrm{mL}$.

\section{HCV Genotyping}

The HCV genotype was determined by Abbott real-time HCV genotype II in vitro reverse-transcriptase RT-PCR assay. HCV RNA was extracted from $500 \mu \mathrm{L}$ of the serum from $\mathrm{HCV}$-infected individuals in the automated extractor Abbott m2000sp, according to the manufacturer's instructions. The Abbott m2000rt device was then used for automated RT-PCR amplification and detection of PCR products according to the manufacturer's instructions. $\mathrm{HCV}$ RNA levels were expressed in IU/mL.

\section{IL28B Genotyping}

Patients were genotyped for the IL28B promoter single nucleotide polymorphism (SNP) at position -3176C/T (rs12979860) using primers and probes from Light Mix Kit IL28B (Cat. No. 400588-32 TIB MOL-BIOL, Berlin, Germany). The quantitative (q) RT-PCR method was performed in a Light Cycler 2.0 instrument (Roche Diagnostics, Mannheim, Germany). Genotyping was performed on genomic DNA isolated from peripheral blood samples.

Liver Fibrosis Assessment

The histopathological assessment of liver fibrosis and necroinflammatory grade was defined using transient elastography ( $\mathrm{Fi}-$ broScan ${ }^{\circledR}$, Paris, France), and scored using the METAVIR system. Final liver stiffness values were reported in kilopascals.

\section{ART}

Patients were treated with standard ART in accordance with standard criteria for exclusion and inclusion (Table 1). The serum aminotransferase levels were regularly checked prior to the start of the treatment and again after 72 weeks.

\section{Results}

Out of 842 coinfected patients, $\mathrm{CHC}$ infection cleared spontaneously in 16 . These individuals became HCV RNA-negative with a SVC. They were followed up from 2000 to 2013 for a range of 3-12 years. Demographic, clinical, and laboratory characteristics of the $16 \mathrm{HIV} /$ HCV coinfected patients who experienced spontaneous HCV clearance are presented in Table 1. All patients had been illicit intravenous drug-users when coinfected with $\mathrm{HIV} / \mathrm{HCV}$. 


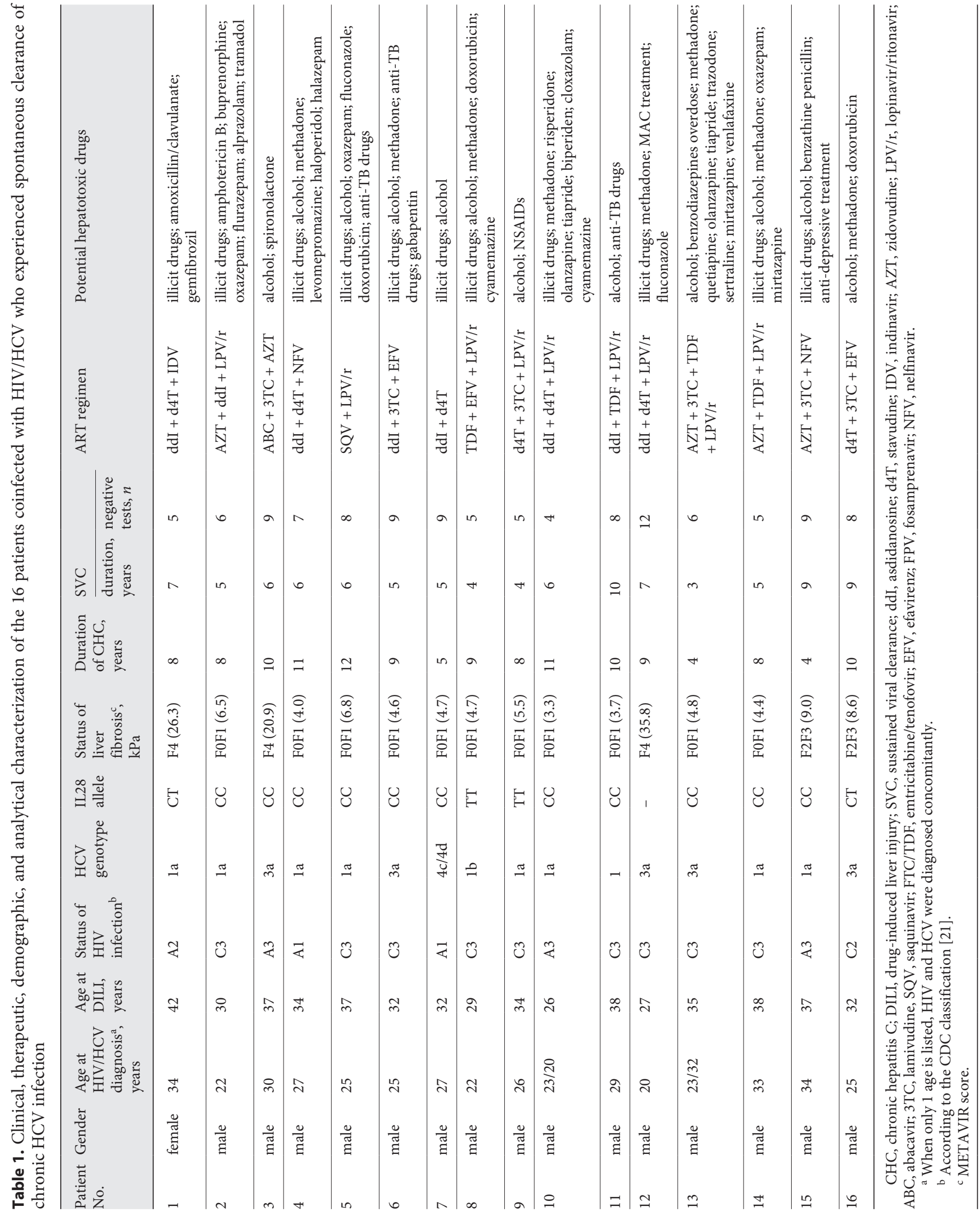




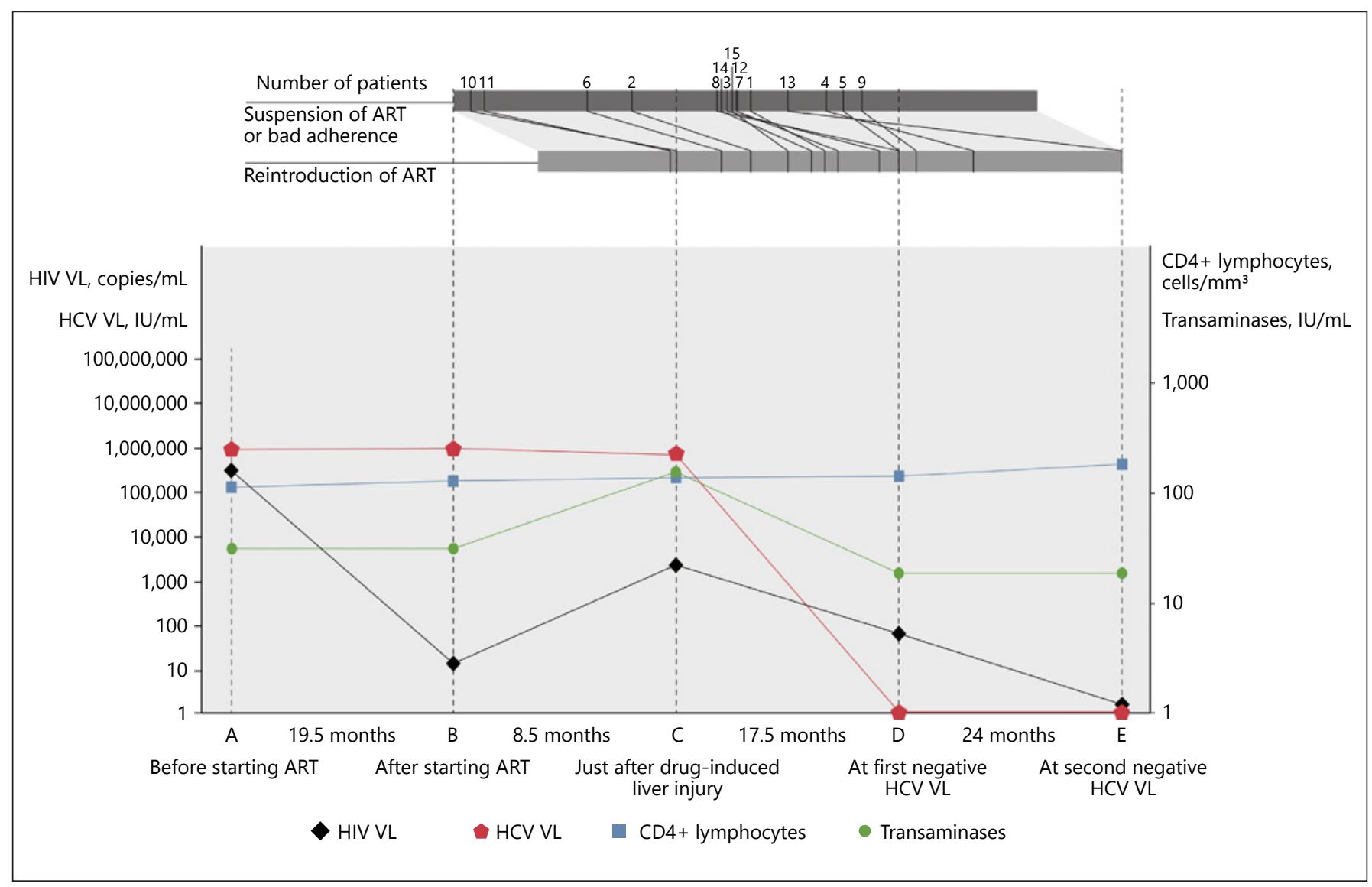

Fig. 1. Analytical and clinical course summary of the 16 patients including the median values of HIV viral load (VL), HCV VL, CD4+ lymphocytes, and transaminases at 5 points in time, as well the median time period between points. The upper part illustrates the moment at which each patient suspended and reintroduced ART therapy. Missing data: HIV VL [point C] in 1 patient; transaminases [point D] in 1 patient; HCV VL [point A] in 8 patients; HCV VL [point B] in 12 patients; HCV VL [point C] in 8 patients).

All patients were treated with standard ART (Table 1). In combination with this, most of them were on other hepatotoxic drugs such as alcohol (11 patients), illicit drugs (11 patients), methadone (7 patients), and antituberculosis drugs ( 3 patients), among others (Table 1). During the follow-up period, they stopped consuming most of these potential hepatotoxic drugs, including ART.

Median duration of $\mathrm{CHC}$ infection in these patients was 9 years. Median time span between drug-induced liver injury (DILI) and the first negative RT-PCR test for HCV infection was 15.5 months. The follow-up time of SVC ranged from 3 to 10 years and was defined as the $\mathrm{HCV}$ viral load being undetectable on RT-PCR $\geq 4$ times (at least 6 months apart).

$\mathrm{HCV}$ viral load, transaminases and CD4+ lymphocytes were evaluated at 5 points in time (Fig. 1, 2): A, be- fore patients started ART; B, after patients started ART; C, just after DILI; D, at first test for negative HCV viral load; E, at the second test for HCV viral load, that confirmed SVC. Figure 1 presents the mean values of these features at each time point as well the median interval between time points. Figure 2 presents the features for each of the 16 coinfected patients.

\section{Viral Load Test}

\section{HCV RNA Quantification}

$\mathrm{CHC}$ was detected in 9 patients according to 2 positive RT-PCR test results a year apart. In the other 7 patients, it was first diagnosed according to clinical, laboratory, and radiological data (i.e., a positive HCV antibody test, liver function tests, and ultrasound data), with a confirmation 1 year later by a positive RT-PCR test result for HCV RNA. 


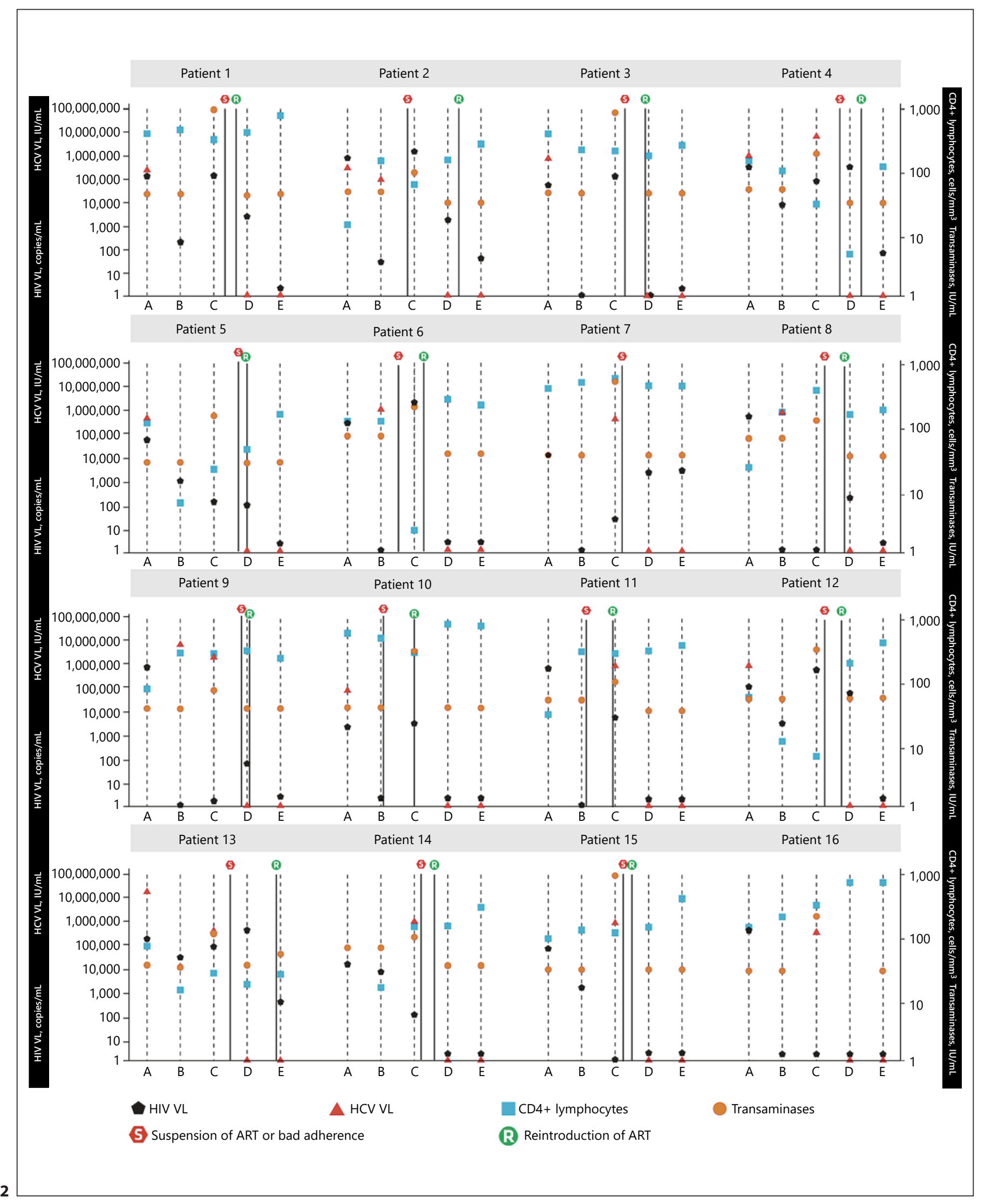

(For legend see next page.) 
HIV RNA Quantification

HIV viral load decreased when patients started ART, increased with the temporary suspension of ART, and decreased after its reintroduction. HIV viral load was undetectable in 12 patients at time of the second negative $\mathrm{HCV}$ test at point $\mathrm{E}$.

\section{HCV Genotyping}

The HCV genotype 1 was the most prevalent genotype (in 10 patients), followed by genotype 3 (in 5 patients) and genotype 4 (in 1 patient).

\section{IL28B Genotyping}

IL28B genotyping was performed in all 16 patients with CHC. Eleven had IL28B genotype CC, 2 had IL28B genotype CT, and 2 had IL28B genotype TT (Table 1).

\section{Liver Fibrosis Assessment}

Table 1 summarizes the histological findings for the study population. Mild fibrosis (METAVIR score: F0 or F1) was observed in 11 patients and severe fibrosis (F3 or F4) in 5. The time span between the diagnosis of coinfection and DILI ranged from 3 to 12 years (median 7 years).

\section{Antiretroviral Therapy}

Fourteen patients had protease inhibitors in their ART scheme. Fifteen of the 16 coinfected patients had ART suspended, either by themselves or by a medical opinion due to the hepatotoxicity (Fig. 1). ART was stopped in 4 patients at the beginning of the DILI and in 11 others after DILI was confirmed (point C). All patients who suspended ART did so before the first negative HCV result was obtained (point D). ART was reintroduced in 14 of these 15 patients (in 9 of them prior to point $\mathrm{D}$ ).

\section{Transaminases}

Serum transaminases levels were moderately elevated in half of the patients (points A and B). When DILI occurred, these values increased in all patients (point $C$ ):

Fig. 2. Analytical and clinical course summary of the 16 patients, including the median values of HIV viral load (VL), HCV VL, CD4+ lymphocytes, and transaminases for each patient and each point in time: A, before patients started ART; B, after patients started ART; C, just after drug-induced liver injury; $D$, at first test negative for HCV VL; E, at second test for HCV VL, that confirmed SVC. S, suspension of ART or bad adherence; R, reintroduction of ART.

Spontaneous HCV Clearance in HIV Patients grade 2 in 7 patients, grade 3 in 4 patients, and grade 4 in 5 patients. The elevated transaminase levels normalized when the HCV RNA became negative (point D).

\section{CD4+ Lymphocytes}

ART influences the immune system and as the amount of CD4+ lymphocytes increases, the HIV viral load decreases. After the reintroduction of ART, a slight increase in CD4+ count with a good remaining score was noted, with a median value of 212 cells $/ \mathrm{mm}^{3}$ at point $\mathrm{D}$ and 326 cells $/ \mathrm{mm}^{3}$ at point $\mathrm{E}$, respectively.

\section{Discussion}

We have described the largest case series, to our knowledge, of spontaneous $\mathrm{HCV}$ clearance in $16 \mathrm{HIV} / \mathrm{HCV}$ coinfected patients with $\mathrm{CHC}$.

Our data showed that all 16 patients displayed transaminase flare-ups and a possible DILI. This event occurred due to acute exposure to ART hepatotoxicity, other hepatotoxic drug intake (e.g., illicit drugs and alcohol), and the more rapid and severe progression of $\mathrm{CHC}$ among HIV-infected patients [21].

In the period of HCV clearance, only 1 patient was on ART and the other 15 had already suspended ART. All 16 patients had suspended or decreased the intake of most of the other hepatotoxic drugs. Furthermore, both events (i.e., the suspension of ART and DILI) took place prior to SVC. However, ART was reintroduced in 14 out of 16 patients.

Despite the spontaneous cure of $\mathrm{CHC}$ in $\mathrm{HIV} / \mathrm{HCV}$ coinfected patients being a rare phenomenon [25], some case reports have been identified [10-28]. The majority included patients with transaminase flare-ups [11, 13-15, $19,20,22,24,25]$. In fact, a time association between transaminase flare-up and SVC was also evident in the patients in our study.

Progression to $\mathrm{CHC}$ is greater when the immune response is inadequate [29], particularly in $\mathrm{HIV} / \mathrm{HCV}$ coinfected patients [30] or when a stimulus is not strong enough to stimulate the immune system.

Our results showed that a high proportion of patients (11 patients or $73.3 \%$ ) had polymorphism CC in the IL28B alleles, which is proven to be more genetically primed to clear HCV infection from the organism [24]. This effect of spontaneous clearance of HCV cannot be solely attributed to the presence of polymorphism CC in IL28B alleles despite the high proportion of patients with this phenotype. In fact, although Stenkvist et al. [24] and 
Frias et al. [26] presented only patients with polymorphism CC, Grint et al. [27] described patients with polymorphism CT. To the best of our knowledge, ours is the second study to describe this event in patients with polymorphism CT and the first to describe it in patients with polymorphism TT in IL28B alleles.

Regarding the HCV genotype, although the majority of patients in our study and other reports present with genotype 1 or 3 , there are several reports on patients with genotype $2[13,15,22,24]$ or $4[23-25,28]$, possibly meaning that this might not be a limiting fact for SVC clearance in HIV-infected patients with CHC.

Endogenous interferon (IFN)- $\alpha$ might also play a role in the replication of HCV. High levels of HIV viral load are associated with high levels of endogenous IFN- $\alpha$ [31]. With ART-based therapy, coinfected patients achieved a decrease in HIV viral load. Levels of endogenous IFN- $\alpha$ therefore decrease $[29,32]$, leading to an increase of $\mathrm{HCV}$ viremia $[31,33,34]$ which may possibly influence in the increase in transaminase levels. On the other hand, when ART is suspended, as occurred in 15 of our patients, HIV viral load and endogenous IFN- $\alpha$ levels stay elevated, and this might play an important role in the clearance of $\mathrm{HCV}$. This may explain the association between the suspension of ART and the SVC of HCV chronic infection in these patients. Torti et al. [19] have already proposed a hypothesis, which includes the production of endogenous IFNs. They described a different perspective, however, proposing that ART hepatotoxicity could induce a cytokine profile in the liver. Both mechanisms might be possible explanations for the results obtained in our study.

Our study has several limitations. Although $\mathrm{CHC}$ was identified in 9 patients by precise quantitative RT-PCR testing ( 1 year apart), it was initially diagnosed in 7 by clinical methods (the ELISA test for positive antibodies against $\mathrm{HCV}$ ), findings which were later confirmed by RT-PCR test (after $>1$ year). This happened because, at the time of primary testing of these 7 patients, the RTPCR method was not yet available at the hospital.

The second limiting factor was the fact that it was not always easy to determine the exact moment of clearance, meaning that the time span between points $\mathrm{C}$ and $\mathrm{D}$ varied depending on the time of the RT-PCR screening. Nevertheless, the clearance was achieved in a period of $<15.5$ months.

It was also difficult to summarize the data, deal with the clinical history, and present the time course from this large case series in simple and easy-to-interpret graphs. Thus, we selected the previously described 5 points in time and summarized them in Fig 1,2. This meant there were missing data, mostly regarding HCV viral load, at certain points in time.

\section{Conclusion}

Our study presents an interesting therapeutic and immune-pathogenic hypothesis, i.e., the conjugation of DILI and ART suspension in HIV-infected patients with $\mathrm{CHC}$, which may lead to new perspectives on the management of these coinfected patients.

Our hypothesis is based on clinical observations of a large case series, i.e., 16 patients with SVC of HCV in $\mathrm{HIV}$-infected patients with CHC. This is the first study to describe this event in patients with IL28B polymorphism TT. Further studies on the immunologic, viral, and biochemical aspects of the clearance of chronic HCV infection in HIV-infected patients must be developed.

\section{Acknowledgements}

We thank A. Águas, MD PhD, and L. Georgievska, PhD, for the critical revision of the manuscript, and R. Serrão, $\mathrm{MD}$, for assisting with data acquisition.

\section{Statement of Ethics}

The study was approved by The Ethics Committee for Health of the Centro Hospitalar S. João and the Faculty of Medicine of University of Porto (ethics ref. No. 329/2015). In accordance with the Declaration of Helsinki, no written informed consent was obtained for this retrospective study.

\section{Disclosure Statement}

The authors declare that there are no conflicts of interest.

\section{Funding Sources}

This study was not supported by any funding sources 


\section{References}

1 Thomas DL, Astemborski J, Rai RM, et al: The natural history of hepatitis $\mathrm{C}$ virus infection: host, viral, and environmental factors. JAMA 2000;284:450-456.

2 Seeff LB: Natural history of chronic hepatitis C. Hepatology 2002;36:S35-S46.

3 Micallef JM, Kaldor JM, Dore GJ: Spontaneous viral clearance following acute hepatitis $\mathrm{C}$ infection: a systematic review of longitudinal studies. J Viral Hepat 2006;13:34-41.

4 GBD 2016 Disease and Injury Incidence and Prevalence Collaborators: Global, regional, and national incidence, prevalence, and years lived with disability for 328 diseases and injuries for 195 countries, 1990-2016: a systematic analysis for the Global Burden of Disease Study 2016. Lancet 2017;390:1211-1259.

5 Monga HK, Rodriguez-Barradas MC, Breaux $\mathrm{K}$, et al: Hepatitis $\mathrm{C}$ virus infection-related morbidity and mortality among patients with human immunodeficiency virus infection. Clin Infect Dis 2001;33:240-247.

6 Sulkowski M: Treatment of hepatitis C in $\mathrm{HIV}$-infected persons: a work in progress. J Hepatol 2008;48:5-7.

7 Fleming CA, Craven DE, Thornton D, Tumilty S, Nunes D: Hepatitis C virus and human immunodeficiency virus coinfection in an urban population: low eligibility for interferon treatment. Clin Infect Dis 2003;36:97-100.

8 Nakamoto S, Kanda T, Shirasawa H, Yokosuka O: Antiviral therapies for chronic hepatitis $\mathrm{C}$ virus infection with cirrhosis. World J Hepatol 2015;7:1133-1141.

9 Watanabe H, Saito T, Shinzawa H, et al: Spontaneous elimination of serum hepatitis $\mathrm{C}$ virus (HCV) RNA in chronic HCV carriers: a population-based cohort study. J Med Virol 2003;71:56-61.

10 Omiste T, Ruiz M, López G, Ramos C: Sustained spontaneous remission of chronic hepatitis $\mathrm{C}$ coinfection in HIV . Enferm Infecc Microbiol Clin 2007;25:290.

11 Fialaire P, Payan C, Vitour D, Chennebault JM, Loison J, Pichard E, Lunel F: Sustained disappearance of hepatitis $\mathrm{C}$ viremia in patients receiving protease inhibitor treatment for human immunodeficiency virus infection. J Infect Dis 1999;180:574-575.

12 Bhagat V, Foont JA, Schiff ER, Regev A: Spontaneous clearance of hepatitis $C$ virus after liver transplantation in two patients coinfected with hepatitis $C$ virus and human immunodeficiency virus. Liver Transpl 2008;14: 92-95.
13 Weissbrich B, Langmann P, Schubert J, Jassoy $\mathrm{C}$, Klinker H: Resolution of HCV infection in a HIV-infected patient under HAART after several hepatitis flare-ups. Eur J Med Res 2003;8:8.

14 Ranieri R, Santambrogio C, Veronelli A, Pontiroli AE: Hepatitis C viremia persistently suppressed by HAART. Clin Infect Dis 2003; 36:1086-1087.

15 Falconer K, Gonzalez VD, Reichard O, Sandberg JK, Alaeus A: Spontaneous HCV clearance in $\mathrm{HCV} / \mathrm{HIV}-1$ coinfection associated with normalized CD4 counts, low level of chronic immune activation and high level of T cell function. J Clin Virol 2008;41:160-163.

16 De Rosa FG, Audagnotto S, Bargiacchi O, et al: Resolution of HCV infection after highly active antiretroviral therapy in a HIV-HCV coinfected patient. J Infect 2006;53:1-4.

17 Endo T, Fujimoto K, Nishio M, Yamamoto S, Obara M, Sato N, Koike T: Case report: clearance of hepatitis $\mathrm{C}$ virus after changing the HAART regimen in a patient infected with hepatitis $C$ virus and the human immunodeficiency virus. J Med Virol 2009;81:979-982.

18 Pérez-Olmeda M, García-Samaniego J, Soriano V: Hepatitis C viraemia in HIV-HCV coinfected patients having immune restoration with highly active antiretroviral therapy. AIDS 2000;14:212.

19 Torti C, Barnes E, Quiros-Roldan E, Puoti M, Carosi G, Klenerman P: Suppression of hepatitis $C$ virus replication is maintained long term following HAART therapy, in an individual with $\mathrm{HCV} / \mathrm{HIV}$ co-infection. Antivir Ther 2004;9:139-142.

20 Zeitoun JD, Mallet V, Chaix ML, Viard JP, Blanche S, Pol S: Stable recovery from $\mathrm{HCV}$ in HIV-HCV co-infection under antiretroviral therapy. J Clin Virol 2007;40:71-73.

21 Manfredi R, Dentale N, Calza L: Spontaneous clearance of chronic hepatitis $\mathrm{C}$ infection in a patient with a 20 -year-old HIV-hepatitis C co-infection and chronic active hepatitis. Int J STD AIDS 2012;23:e48-e50.

22 Yokozaki S, Takamatsu J, Nakano I, et al: Immunologic dynamics in hemophiliac patients infected with hepatitis $C$ virus and human immunodeficiency virus: influence of antiretroviral therapy. Blood 2000;96:4293-4299.

23 Vispo E, Barreiro P, Plaza Z, Fernández-Montero JV, Labarga P, De-Mendonza C: Spontaneous HCV clearance in HIV patients with chronic hepatitis C-bearing IL28B-CC alleles using antiretroviral therapy. AIDS 2014;28: 1473-1478.

24 Stenkvist J, Nyström J, Falconer K, Sönnerborg A, Weiland O: Occasional spontaneous clearance of chronic hepatitis C virus in HIVinfected individuals. J Hepatol 2014;61:957961.
25 Algoud M, Tissot-Dupont H, Menard A, et al: Spontaneous clearance of chronic hepatitis $\mathrm{C}$ virus infection in $\mathrm{HIV}$-positive patients, southeastern France. Clin Res Hepatol Gastroenterol 2017;41:e87-e89.

26 Frias M, Rivero-Juarez A, Tellez F, et al: Spontaneous clearance of chronic hepatitis $\mathrm{C}$ is rare in $\mathrm{HIV}$-infected patients after effective use of combination antiretroviral therapy. PLoS One 2017;12:e177141.

27 Grint D, Tedaldi E, Peters L, et al: Hepatitis C virus (HCV) RNA profiles among chronic $\mathrm{HIV} / \mathrm{HCV}$-coinfected individuals in ESPRIT; spontaneous HCV RNA clearance observed in nine individuals. HIV Med 2017;18:430434.

28 Mora-Peris B, Goklin RD, Muir D, et al: Apparent spontaneous clearance of chronic hepatitis $\mathrm{C}$ virus infection in a HIV co-infected patient with decompensated cirrhosis: a case report. AIDS 2015;29:982-985.

29 Martín-Carbonero L, Benhamou Y, Puoti M, et al: Incidence and predictors of severe liver fibrosis in human immunodeficiency virusinfected patients with chronic hepatitis C: a European collaborative study. Clin Infect Dis 2004;38:128-133.

30 Williams R: Global challenges in liver disease. Hepatology 2006;44:521-526.

31 Bower WA, Culver DH, Castor D, Wu Y, James VN, Zheng H: Changes in hepatitis C virus $(\mathrm{HCV})$ viral load and interferon-alpha levels in HIV/HCV-coinfected patients treated with highly active antiretroviral therapy. J Acquir Immune Defic Syndr 2006;42:293297.

32 Castro KG, Ward JW, Slutsker L, Buehler JW, Jaffe HW, Berkelman RL: 1993 revised classification system for HIV infection and expanded surveillance case definition for AIDS among adolescents and adults. MMWR Recomm Rep 1992;41:1-19.

33 Puoti M, Gargiulo F, Roldan EQ, et al: Liver damage and kinetics of hepatitis $\mathrm{C}$ virus and human immunodeficiency virus replication during the early phases of combination antiretroviral treatment. J Infect Dis 2000;181: 2033-2036.

34 Cooper CL, Cameron DW: Review of the effect of highly active antiretroviral therapy on hepatitis $\mathrm{C}$ virus (HCV) RNA levels in human immunodeficiency virus and $\mathrm{HCV}$ coinfection. Clin Infect Dis 2002;35:873-879. 